\title{
Impact of H.R practices on employee's job satisfaction: A case study from fertilizer industry of Pakistan
}

\author{
Afzal Ahmed ${ }^{a}$, Yaser Zaman ${ }^{a^{*}}$ and Attique Khattak
}

${ }^{a}$ Master Scholar, University of Haripur, Pakistan

${ }^{b}$ Lecture, University of Haripur, Pakistan

CH R O N I C L E

Article history:

Received: October 1, 2016

Received in revised format: No-

vember 16, 2016

Accepted: February 15, 2017

Available online:

February 15, 2017

Keywords:

Employee's job satisfaction

HR practices

Training and development

Recruitment and selection

Compensation and benefit

\section{A B S T R A C T}

\begin{abstract}
This study investigates the impact of human resources (HR) practices, recruitment and selection, training and development, compensation and benefits, on employee's job satisfaction in fertilizer sector of Pakistan. A pre-tested questionnaire was distributed and two hundred respondents provided useable information. The result of the study shows a positive relationship between HR practices and job performance, which indicates fair recruitment and selection, better training and development opportunities and attractive compensation and benefit packages increase the level of satisfaction of employees.
\end{abstract}

\section{Introduction}

Organizations must adjust themselves to different human resources management practices to attain their key objectives. A company's human resource management practices must create employee's knowledge, skills, and inspiration (Dessler, 2007). Different models of human resource oversaw economy need and has been produced starting with some chances on occasion. All these models bring some knowledge and the human resource expert will adequately deal with those human resource knowledge. The Harvard model Beer et al. (1984) meets expectations concerning concept and these are a key guide on aid all supervisors on their relations for workers and condensed on the human or delicate perspective about HRM. It strives toward worker promise which is not controlled. It meets expectations that employees required will make congruent, skillful and cosset compelling. The Michigan model Fombrun et al. (1984) concentrates with respect to diligent HRM. It holds individuals if we figured out how much a viable resource that acquired cheaply, utilized sparingly, produced and * Corresponding author.

E-mail address: yaser.zaman004@gmail.com (Y. Zaman) 
misused fully. The influence from the practices of human resource management (HRM) prominently known as HR practices (Delaney \& Huselid, 1996; Katou \& Budhwar, 2007). There are a number of factors that impact satisfaction of the employees both informed and creating nations. Researcher need to analyze that relationship of satisfaction between with pay, promotion, border benefits, working condition, help for research, disappointments and outrage on his/her staff assessment and appraisal system. This study is a focus to raise a seeing in regards the "'effect of HRM practices on employee's job satisfaction" around Pakistani worker in the fertilizer sector.

\section{Literature review}

HRM have been formed as a management idea which lays stress on the singular specialist and requires on treat individuals likewise stakes as opposed expense (Wilkinson 1990). If it might have been generally acknowledged as a new administration practice, the idea remains unclear similarly as it will be connected in distinctive routes. Guest (1987) identifies three primary methodologies to HRM: firstly, Human Resource Management is another label to workforce management, pointing that organizations rename their workforce division without fundamentally evolving practices, Secondly, Human Resource Management Concerning concept an approach for re-conceptualizing and reorganizing staff parts and describing the worth of effort about faculty department, Thirdly HRM Similarly as a completely new methodology to management for a uniqueness which lies in the joining from human resource under key management and the accentuation with respect to full and certain use for these resources.

\subsection{Recruitment and selection}

This includes two interrelated courses, recruitment is the procedures for generating a pool from claiming fit individuals to apply to work with an organization whiles Selection is the transformation by which particular instruments would utilize to look over a pool of applicants suitableness for the work bringing under attention management objectives and lawful necessities (Bratton \& Gold, 2012). Armstrong (2001) categories recruitment and Selection under three stages: characterizing requirement, attracting hopefuls and selecting hopefuls. Those recruitment and Selection procedure may be a standout amongst the vital HRM capacities concerning concept it will be those side of the point for entrance under the vast majority organizations and the place practically organizations initiate talents that drive their objectives and enthusiasm. It reflects the necessities and rationality of the organization as reflected in the bore from claiming people picked for that occupation. Organization's strategy and the dream of the organization could make acknowledged as a pointer of the endeavors of the recruitment and it is a sample of the inward variables ( $\mathrm{Nel}$ et al., 2008). Concerning concept, a professional HR manager, it is indispensable will bring that competency and capability with select fit workers and put them for suitableness worth of effort position (Morques, 2007).

\subsection{Training and development}

Training is the formal and precise adjustment of conduct through taking in which concerning concept an after effect of education, instruction, improvement and arranged experience is shared (Armstrong, 2001). Training could be at work alternately off the work contingent upon the compelling reason being referred to proper training may be needed to different necessities. A thorough examine led toward Koch and McGrath (1996) showed that organizations that captivate a deliberate training for their workforce need aid less averse should delight in those remunerates of that's only the tip of the iceberg profitable workforce. The discoveries of Armstrong, (2001) uncover that training impacts authoritative commitment, member information and organization-based respect toward oneself. Similarly, Bartel (1994) found that venture to training supports employee resolve and builds employees trust and improve performance. In general, training and development policies permits workers will get more 
excellent competencies that would necessary on performing their occupations proficiently and successfully (Harrel \& Tzafrir, 1999).

\subsection{Compensation and Benefits}

Compensation and benefit may be a precise procedure on assessing the performance of a worker following a sure time (Leonard, 1990). Compensation and benefit additionally impact other HR practices, and employee relations (Fulmer et. al., 2003). Compensation is the bonuses submitted to the worker to provide them some financial benefits and compensation procedure could a chance to be isolated with immediate money related compensation and backhanded payment if it monetary alternately nonfinancial. Caruth \& Handlogten (2001) stated that employees need inspiration when there would monetary remunerates straightforwardly tied with their performance. Leonard \& Jonathan (1990) expressed that when those organization adopts long haul want about incentives, it will get and build a greater amount in a row over those organizations that didn't would. Altarawneh and Al-Kilani (2010) state that "employees are persuaded when there would monetary remunerates straightforwardly tied on their performance. Compensation may be a vital strategy in the organization, the place it could influence on the employer's plausibility on lure new applicants, get employee's devotion and guarantee the most extreme level from claiming performance with help that organization objective and target starting with those (Caruth \& Handlogten, 2001)

\subsection{Job Satisfaction}

A large portion alluded definition of job satisfaction and the best have been advertised toward Locke (1976) who characterized job satisfaction as concerning concept, a pleasing alternately sure enthusiastic state coming about or after of the assessment of a person's particular occupation. Employment satisfaction may be additionally characterized as individual's general state of mind in regards as much alternately her particular occupation (Robbins, 1999). An employee job satisfaction implies that the level from which employee feel happy and pleasure as stated by occupation and the satisfaction level about employees likewise connected with increment yield of the company, low truancy of the employees and low turnover (Hackman \& Oldham, 1975). Robbins (1999) said that inspiration may be nearly identified with particular job satisfaction. Particular job satisfaction needs a noteworthy impact ahead employee's authoritative commitment, turnover, absenteeism, tardiness, accidents, and grievances (Byars \& Rue, 1997; Moorhead \& Griffin, 1999)

\subsection{HR practices and Job satisfaction}

HR practices particular job satisfaction are examined generally in distinctive parts of the globe. It may be accepted that HR practices need aid nearly connected with job satisfaction (Ting, 1997). On a large number of researcher and professionals trust that HR practices bring about finer level about job satisfaction which enhances authoritative performance. Yu and Egri (2005) demonstrated the effects of HR practices on job satisfaction and find out there sustain a positive relationship between them. The point of recruitment and selection move forward and fit in the middle of employees and the organization, teams, fill in requirements, and thus, should make a superior organization in earth (Tzafrir, 2006). Complex publicizing recruitment and selection framework might guarantee a preferred fit between the individual's abilities and the organization's prerequisite and then make the employees love their work (Fernandez, 1992). Katou and Budhwar (2007) clinched alongside an investigation on the Greek manufacturing organizations found that recruitment and selection have been decidedly identified with the greater part authoritative performance variables and make employees satisfied. Training and development allude all and at whatever exert should move forward current about future employee's skills, abilities, and learning and make them feel happy about their role (Aswathappa, 2013). Training and development need a noteworthy sure sway around employees job satisfaction (García, 2005). Thang and Buyens (2008) stated that training and development prompt unrivaled knowledge, skills, abilities, 
attitudes, and conduct technique from claiming employees that eventually improve phenomenal money related and non-fiscal performance of the organization. Compensation and benefits allude with every last bit from the pay or remunerates setting the employees and emerging starting with their employment (Dessler, 2008). Compensation and benefit will be a whole lot critical to workers on it may be a standout amongst the principal purposes behind which individuals fill in and employee's existing status in the society, satisfaction, loyalty, and benefit are likewise impacted by that payment (Aswathappa, 2013). Ting (1997) on an investigation on the employees from claiming US government discovered that compensation and benefit might have been a standout amongst the vast majority critical determinants of particular job satisfaction. Better compensation and benefits relations make a suitable environment for all workers that eventually impacts job satisfaction (Khan \& Taher, 2008).

\section{Research Methodology}

The objective of the research is to check that is there any Impact of H.R Practices on Employee Job Satisfaction. The Methodology provides the detail of the methods and procedures to be used for gathering data, how it will be analyzed, interpreted and how its results/conclusions will be drawn. Data was collected through questionnaires which were adopted from previous studies of Absar et al. (2010), Brayfield and Rothe (1951), Hazara Phosphate and Fauji fertilizer were selected for sampling and 200 respondent provide useable information.

\subsection{Hypotheses}

H1: There is a significant relationship between Recruitment \& Selection and Job Satisfaction.

H2: There is a significant relationship between employee Training \& development and Job Satisfaction.

H3: There is a significant relationship between Compensation \& Benefits and Job Satisfaction

\subsection{Conceptual framework}

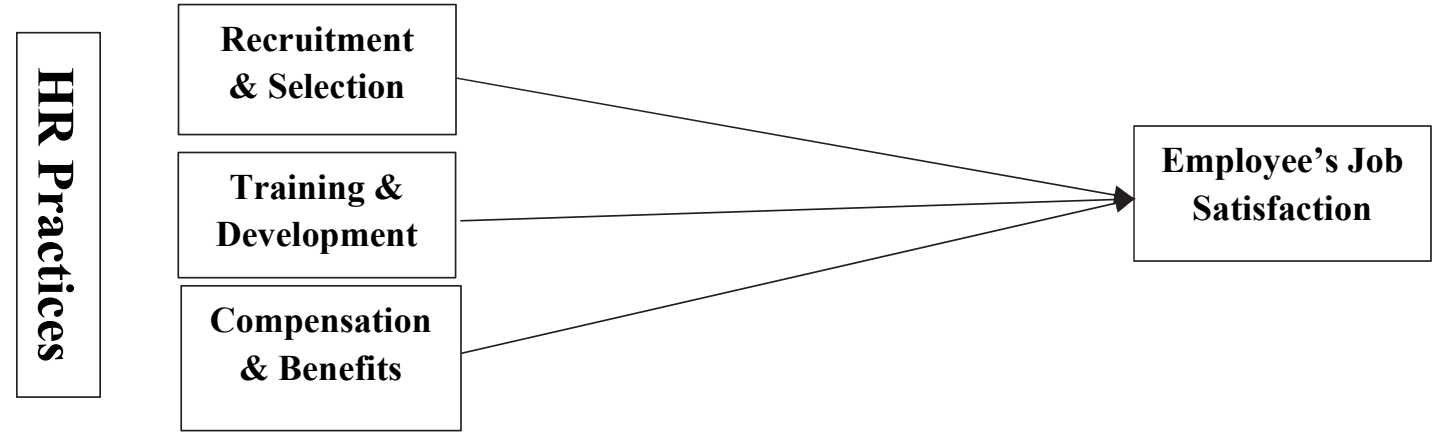

\section{Data analysis and results}

\subsection{Descriptive analysis}

Two descriptive variables are considered in this study which is gender and age. As the data for this research was collected from two fertilizer companies where the majority of the workers are male and the sample of this study contained $100 \%$, male respondent. Age of respondents is divided into three categories, in the first slab the age limit is Below 25, in the second category the age limit is from 25 to 30 , in the third category the age limit is from 31 to 40 . So according to this below the age of 25 are $15 \%$, from 25 to 30 respondents are $74 \%$, in the third category that is 31 to 40 age limit there are only $11 \%$. 


\subsection{Correlation analysis}

Correlation analysis measures the power of the relationship between independents and Dependent variable. The utmost commonly used correlation coefficient, called the Pearson correlation coefficient, measures the strength of the independent variables and dependent variable.

Table 1

Correlation analysis

\begin{tabular}{|c|c|c|c|c|c|}
\hline & & $\begin{array}{c}\text { Job } \\
\text { Satisfaction }\end{array}$ & $\begin{array}{c}\text { Training And De- } \\
\text { velopment }\end{array}$ & $\begin{array}{l}\text { Compensation And Ben- } \\
\text { efit }\end{array}$ & $\begin{array}{l}\text { Recruitment And Se- } \\
\text { lection }\end{array}$ \\
\hline \multirow{2}{*}{ Job satisfaction } & Pearson Correlation & 1 & & & \\
\hline & Sig. (2-tailed) & & & & \\
\hline \multirow{2}{*}{ Training and development } & Pearson Correlation & $.486^{* *}$ & 1 & & \\
\hline & Sig. (2-tailed) & .000 & & & \\
\hline \multirow{3}{*}{ Compensation and benefit } & Pearson Correlation & $.340^{* *}$ & $.240^{* *}$ & 1 & \\
\hline & Sig. (2-tailed) & .000 & .008 & & \\
\hline & Pearson Correlation & $.497^{* *}$ & $.269^{* *}$ & $.197^{* *}$ & 1 \\
\hline \multirow[t]{2}{*}{ Recruitment and selection } & Sig. (2-tailed) & .001 & .007 & .003 & \\
\hline & $\mathrm{N}$ & 100 & 100 & 100 & 100 \\
\hline
\end{tabular}

**. Correlation is significant at the 0.01 level (2-tailed).

*. Correlation is significant at the 0.05 level (2-tailed).

\subsection{Regression analysis}

Two techniques of regression analysis are applied in this study which is Model summary and coefficient. The model summary shows the overall fitness of the model and it giving specific consideration to the value of $R$. To determine the statistically significant unique contribution of each variable to the equation will check the value in the table of the coefficient. If the Sig value is less than $.05(.01, .0001$ etc.) then the variable is making a significant unique contribution to the prediction of the dependent variable. If greater than .05 then can conclude that variable is not making a significant unique contribution to the prediction of the dependent variable. In this case, all the variable making a unique contribution having significant values which are $.000, .001$ and .002 .

Table 2

Model summary

\begin{tabular}{ccccc}
\hline Model & $\mathrm{R}$ & $\mathrm{R}$ Square & Adjusted R Square & Std. Error of the Estimate \\
1 & .491 & .341 & .317 & .59692 \\
\hline a. Predictors: (Constant), Recruitment and selection, Compensation and benefit, Training and development &
\end{tabular}

\section{Table 3}

Coefficient

\begin{tabular}{lcccc}
\hline Model & B & Std. error & T & Sig. \\
\hline Training and development & .465 & .086 & 2.303 & .000 \\
Compensation and benefit & .276 & .078 & 0.894 & .002 \\
Recruitment and selection & .374 & .097 & 1.075 & .001 \\
\hline
\end{tabular}

Dependent Variable: Job satisfaction

H1: There is a significance relationship between recruitment \& selection and employee's job satisfaction.

For the first hypothesis in Table 1 of correlation and Table, 3 of the coefficient two variables which are Employee Job Satisfaction and Training and Development are correlated. As the statistics are $\mathrm{r}=$ $0.486, \mathrm{~B}=0.465$ and sig. $=0.000$ means there is statistically significant relationship between Employee 
Job Satisfaction and Training and Development. That concludes when any organization gives their employees training and work for the development of their skills then employees become satisfied with their jobs. So our first hypothesis is accepted. Dessler , (2007) concluded the same results.

H2: There is a significance relationship between training and development and employee's job satisfaction.

For the second hypothesis in Table 1 of correlation and Table, 3 of the coefficient, the two variables, Employee Job Satisfaction and Compensation and Benefits are correlated. As the statistics are $\mathrm{R}=$ $0.340, \mathrm{~B}=0.276$ and sig. $=0.000$ which means there is statistically significant and the considerable relationship between Employee Job Satisfaction and Compensation and Benefits. That concludes that fair compensation and benefits lead to employee job satisfaction, our second hypothesis is accepted, Armstrong, (2001) concluded the same results.

H3: There is a significance relationship between compensation and benefits and employee's job satisfaction.

For the third hypothesis in Table 1 of the correlation and Table, 3 of the coefficient, two variables, Employee Job Satisfaction and Recruitment and Selection are correlated. As the statistics are $\mathrm{R}=$ $0.497, \mathrm{~B}=0.374$ and sig $=0.001$ means there is statistically significant and the considerable relationship between Employee Job Satisfaction and Recruitment and Selection. This means that when any organization does fair Recruitment and Selection this will lead towards Employee Job Satisfaction, hence our third hypothesis is accepted, Ghebregiorgis and Karstan (2007) concluded the same results.

\section{Discussion and conclusion}

This study is designed to investigate the impact of Human Resource Management practices on the satisfaction of the employees. There are many HR practices like recruitment and selection, training, performance appraisal, career path, compensation, job definition etc. Only three practices (recruitment and selection, training and development, compensation and benefits) were taken to understand the impact on the job satisfaction of the employees. The findings of these questions showed that there was a good relationship between the employee satisfaction and the HRM practices. The frequencies relating to the working environment and career development opportunities were showing the higher values. So to improve the employee's satisfaction towards their job and organization the management should focus to improve the HRM practices and their qualities. It is concluded that recruitment and selection, training and development, compensation and benefits play a vital role for the satisfaction of the employees.

\subsection{Recommendation}

In today's environment, the human resources are as important as the financial assets and technologies, etc. So organizations have to consider the human resource because these are very important for the betterment of the organization. And as the results of this research shows that the better recruitment and selection, career development opportunities and rewards are more important factors that affect the job satisfaction of employees with the organization. They should be focused and try to improve them. This study provides additional information for the management, the influence of HRM practices toward employee's job satisfaction. The result of the study is the determinant toward making more reliable decision and planning process. The approach of hiring staff into various position should be considered. The administrator should conduct a proper job analysis and evaluation of positions to be filled. Human resources accepting applications when job vacancies have not been posted and it should be reviewed. Effective recruitment and selection attract the right quality and quantity of people to further 
improve the system of MSI, modern technology should be utilized for strategically recruit and selection. Moreover, a recruitment and selection program should be implemented to enhance the capabilities of employees. Training and development enhance the skills of the employees and make them effective and efficient for their job and organization. Related training opportunity and development policies make the employees loyal and beneficial for the organization. Compensation and benefits full filled the financial needs of the employees and make them happy toward their jobs, this may lead to stitch them with their organization and decrease turnover ratios.

\subsection{Limitations and feature research direction}

- $\quad$ There are many other factors which may affect the level of employee job satisfaction but due to time constraint, other factors are not taken for research,

- $\quad$ The sample size of the study was also limited.

- In this study, no intervening or moderating variables are considered.

- $\quad$ This study considers only three human resource practices (recruitment and selection, training and development, compensation and benefits) while other practices should also be used to get more clear picture of the employee's job satisfaction.

- $\quad$ The Sample consists of only the middle classes and only male respondent of fertilizer industry while other employees can be part of the study.

\section{References}

Absar, M. M. N., Azim, M. T., Balasundaram, N., \& Akhter, S. (2010). Impact of human resources practices on job satisfaction: Evidence from manufacturing firms in Bangladesh. Petroleum-Gas University of Ploiesti Bulletin, 62(2), 31-42.

Altarawneh, I., \& Al-Kilani, M. H. (2010). Human resource management and turnover intentions in the Jordanian hotel sector. Research \& Practice in Human Resource Management,18(1).

Armstrong, M. (2001). A Handbook of Human Resource Practice. 8th Ed Kogan Page.

Aswathappa, K. (2013). Human resource management: Text and cases. Tata McGraw-Hill Education.

Bartel, A. P. (1994). Productivity gains from the implementation of employee training programs. Industrial relations: a journal of economy and society,33(4), 411-425.

Beer, M. Spector, B., Lawrence, P.R., Quinn Mills, D and Walt on, T. (1984). Managing Human Resource, New York: Free Press.

Bratton, J., \& Gold, J. (2012). Human resource management: theory and practice. Palgrave Macmillan.

Brayfield, A. H., \& Rothe, H. F. (1951). An index of job satisfaction. Journal of applied psychology, 35(5), 307.

Byars, L. L. \& Rue, L. W. (1997). Human resource management. Irwin (Chicago)

Caruth, D. L., \& Handlogten, G. D. (2001). Managing Compensation (and understanding it too): A handbook for the perplexed. Greenwood Publishing Group.

Delaney, J. T., \& Huselid, M. A. (1996). The impact of human resource management practices on perceptions of organizational performance. Academy of Management journal, 39(4), 949-969.

Dessler, G., (2007). Human Resource Management, Prentice-Hall, Englewood Cliffs, NJ.

Fernandez, G. C. (1992, August). Effective selection criteria for assessing plant stress tolerance. In Proceedings of the international symposium on adaptation of vegetables and other food crops in temperature and water stress (pp. 257-270).

Fombrun, C. J., Tichy, N. M., \& Devanna, M. A. (1984). Strategic human resource management. Wiley.

Fulmer, I. S., Gerhart, B., \& Scott, K. S. (2003). Are the 100 best better? An empirical investigation of the relationship between being a "great place to work" and firm performance. Personnel Psychology, 56(4), 965-993. 
García, M. Ú. (2005). Training and business performance: The Spanish case. The International Journal of Human Resource Management, 16(9), 1691-1710.

Ghebregiorgis, F., \& Karsten, L. (2007). Human resource management and performance in a developing country: The case of Eritrea. The International Journal of Human Resource Management, 18(2), 321-332.

Guest, D. (2002). Human resource management, corporate performance, and employee well-being: Building the worker into HRM. Journal of Industrial relations, 44(3), 335-358.

Guest, D. E. (1987). Human resource management and industrial relations. Journal of management Studies, 24(5), 503-521.

Hackman, J. R., \& Oldham, G. R. (1975). Development of the job diagnostic survey. Journal of Applied psychology, 60(2), 159.

Harel, G. H., \& Tzafrir, S. S. (1999). The effect of human resource management practices on the perceptions of organizational and market performance of the firm. Human resource management, 38(3), 185-199.

Katou, A. A., \& Budhwar, P. S. (2007). The effect of human resource management policies on organizational performance in Greek manufacturing firms. Thunderbird international business review, 49(1), 1-35.

Khan, A. A., \& Taher, M. A. (2008). Human resource management and industrial relations. Dhaka: Abir Publications.

Koch, M. J., \& McGrath, R. G. (1996). Improving labor productivity: Human resource management policies do matter. Strategic management journal,17(5), 335-354.

Leonard, J. S. (1990). Executive pay and firm performance. Industrial \& Labor Relations Review, 43(3), 13S-29S.

Locke, E. A. (1976). The nature and causes of job satisfaction. Handbook of industrial and organizational psychology, 1, 1297-1343.

Marques, J. (2007). HR in all its glory. Human Resource Management International Digest, 15(5), 36.

Moorhead, G., Griffin, R. W. (1999). Organizational behavior organizations. Delhi: AITBS Publishers \& Distributors, 1999.

Nel, P., Werner, A., Haasbroek, G., Poisat, P., Sono, T. \& Schultz, H. (2008). Human Resources Management. 7th Edition. Cape Town: Oxford Southern Africa.

Robbins, S. P., (1999). Organizational behavior Concepts, controversies, applications. New Delhi:

Thang, N. N., Buyens, D. (2008). What we know about relationship between training and firm performance: A review of literature. Paper presented at the 7th International Conference on Ethics and Quality of Work life for Sustainable Development, Bangkok, Thailand, 2008

Ting, Y. (1997). Determinants of job satisfaction of Federal Government Employees, Public Personnel Management, 26(3), 313-334.

Tzafrir, S. S. (2006). A universalistic perspective for explaining the relationship between HRM practices and firm performance at different points in time. Journal of Managerial Psychology, 21(2), 109-130.

Wilkinson, A. (1990). Business Strategy and the management of Labor" University of Durham PhD.

$\mathrm{Yu}, \mathrm{B}$. B., Egri, C. P. (2005). Human resource management practices and affective organizational commitment: A comparison of Chinese employees in a state-owned enterprise and a joint venture. Asia Pacific Journal of Human Resources, 43(3), 332-360.

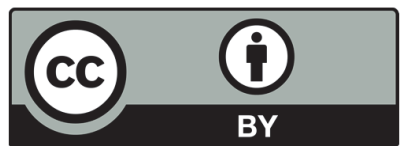

(c) 2017 by the authors; licensee Growing Science, Canada. This is an open access article distributed under the terms and conditions of the Creative Commons Attribution (CC-BY) license (http://creativecommons.org/licenses/by/4.0/). 